\title{
ORIGINAL
}

\section{Effect of Lipid Addition on the Profile of Lipase Production by Mucor javanicus}

\author{
Yasuhiro Naka, Noriaki Hasegawa, and Sigeru Amano \\ Amano Pharmaceutical Co., Ltd. \\ (Nishishiroyashiki-51, Kunotsubo, Nishiharu-cho, Nishikasugai-gun, Aichi-ken, ₹481)
}

\begin{abstract}
While increasing lipase production by Mucor javanicus IAM 6108, reduction in cultivation time and stabilization of lipase in the broth were investigated. The addition of $1 \%$ soybean oil to the initial medium containing 3 $\%$ corn steep liquor, $1 \%$ soluble starch, $0.2 \% \mathrm{KH}_{2} \mathrm{PO}_{4}, 0.05 \% \mathrm{MgSO}_{4} \cdot 7 \mathrm{H}_{2} \mathrm{O}, 0.05 \% \mathrm{KCl}$, and $1 \%$ soybeanyuto reduced the cultivation time of lipase production from $50 \mathrm{~h}$ to $30 \mathrm{~h}$.

Lipase activity in the broth decreased rapidly after reaching a maximum. To avoid this, the $1 \%$ soybean oil was added to the broth at $25 \mathrm{~h}$ of cultivation before the maximum had been reached, As a result, maximum lipase activity was maintained for more than $10 \mathrm{~h}$. This appeared due to the presence of fatty acids or triglycerides with double bonds on the broth.
\end{abstract}

\section{Introduction}

The relationship between lipase production and lipid has been reported on various kinds of microorganism. The addition of lipid to cultivation medium increased the lipase productivity of Mucor javanicus ${ }^{1}$, Candida paralipolytica' ${ }^{2}$, Pseudomonas mephitica ${ }^{3)}$, Chromobacterium viscosum ${ }^{4}$ and Pseudomonas sp. No. $156^{5}$. On the other hand, the lipase production of Rhizopus stolonifer ${ }^{6)}$ was inhibited by lipid. Furthermore, lipoprotein lipase of Rhizopus japonicus ${ }^{\text {? }}$ was effectively excreted from its mycelia by lecithin added to the medium.

In the cource of study on the scale-up of lipase production by Mucor javanicus IAM 6108, the authors found that the addition of soybean oil to the medium reduced the cultivation time with the change of fermentation profile. However, lipase activity in broth decreased rapidly after reaching the maximum. This report describes these facts and how to maintain the maximum value of lipase activity during the late phase of cultivation.

\section{Materials and Methods}

Microorganism and Cultivation : Mucor javanicus IAM 6108 in $100 \mathrm{~mL} / 500 \mathrm{~mL}$-Sakaguchi flask grown by Saiki et al's method " was innoculated into a $30 \mathrm{~L}$-jar fermenter (Liquid volume : $15 \mathrm{~L}$ ) and cultivated at $26{ }^{\circ} \mathrm{C}$ under $15 \mathrm{~L} / \mathrm{min}$ of aeration and $300 \mathrm{rpm}$ of agitation. Mucor javanicus
IAM 6108 and soybean-yuto were gifted by Department of Agricultural Chemistry, Faculty of Agriculture, Tokyo University.

Assay of Lipase ${ }^{8}$ : The solution composed of $5.0 \mathrm{~mL}$ of olive oil-poly (vinyl alcohol) emulsion* and $4.0 \mathrm{~mL}$ of $0.1 \mathrm{M}$ phosphate buffer $(\mathrm{pH} 7.0)$ was put into a reaction tube $(30 \times 120 \mathrm{~mm})$ and preincubated for $5 \mathrm{~min}$ at $37^{\circ} \mathrm{C}$ prior to the addition of enzyme solution.

The reaction mixture was incubated for $30 \mathrm{~min}$ at $37{ }^{\circ} \mathrm{C}$ and the reaction was stopped by the addition of $10.0 \mathrm{~mL}$ of acetone-ethanol mixture (1 $: 1)$. To the mixture, $10.0 \mathrm{~mL}$ of $0.05 \mathrm{~N} \mathrm{NaOH}$ solution and $10.0 \mathrm{~mL}$ of acetone-ethanol mixture (1:1) were added.

The solution was titrated with $0.05 \mathrm{~N} \mathrm{HCl}$ solution under nitrogen gas bubbling. As the blank test, $1.0 \mathrm{~mL}$ of the enzyme solution was added after the termination of reaction with $10.0 \mathrm{~mL}$ of acetone-ethanol mixture $(1: 1)$.

* Olive oil poly (vinyl alcohol) emulsion : $75 \mathrm{~mL}$ of olive oil (JP.XI) and $225 \mathrm{~mL}$ of $2 \%$ poly(vinyl alcohol) solution** was stirred vigously (14 $500 \pm$ $300 \mathrm{rpm}$ ) with keeping at below $10^{\circ} \mathrm{C}$ for $10 \mathrm{~min}$ in use of Homogenizer (Nippon Seiki Co., Ltd.).

** $2 \%$ poly (vinyl alcohol) solution : $4.5 \mathrm{~g}$ of PVA 117 and $0.5 \mathrm{~g}$ of PVA 205 (Kurashiki POVAL) was suspended in $250 \mathrm{~mL}$ of the distilled water and heated at below $80^{\circ} \mathrm{C}$ under stirring to become a clear solution and it was cooled, filtered and supplied. 
to use.

One unit is defined as the amount of the enzyme which liberated $1 \mu \mathrm{mol}$ of free fatty acid in $1 \mathrm{~min}$ under above conditions.

Stability of Lipase in Aqueous solution : Mucor lipase (Lipase M-AP, $20000 \mathrm{u} / \mathrm{g}$, Amano Pharmaceutical) was dissolved in McIlvain buffer ( $\mathrm{pH} 7.0$ ) to get the solution of $0.5 \%$ concentration. The solution was kept at $37^{\circ} \mathrm{C}$ and the residual activity after $30 \mathrm{~min}$ and $60 \mathrm{~min}$ was assayed.

Triglycerides or fatty acids were added to become $5 / 3 \times 10^{-3} \mathrm{M}$ or $5 \times 10^{-3} \mathrm{M}$ respectively of final concentration.

\section{Results}

\section{The change of fermentation profile}

Mucor javanicus IAM 6108 was cultivated by the method described in Materials and Methods. Lipase production reached the maximum value at $50 \mathrm{~h}$ to get the same results as in Saiki et al.'s (Fig. -1). On the other hand, various kinds of

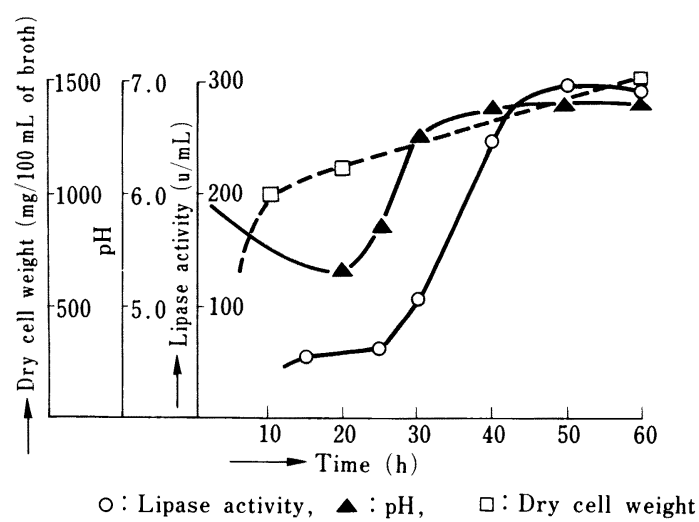

Medium : corn steep liquor $3 \%$, soluble starch $1 \%$, $\mathrm{KH}_{2} \mathrm{PO}_{4} 0.2 \%, \mathrm{MgSO}_{4} \cdot 7 \mathrm{H}_{2} \mathrm{O} 0.05 \%, \mathrm{KCl} 0.05 \%$ and soybean-yuto $1 \%(0.2 \%$ as phospholipid $)$. Initial $\mathrm{pH}$ was 6.0 .

Cultivation was carried out at $26^{\circ} \mathrm{C}$, under $300 \mathrm{rpm}$ of agitation and $15 \mathrm{~L} / \mathrm{min}$ ( $1 \mathrm{vvm}$ ) of aeration by use of $30 \mathrm{~L}$-jar fermenter (Liquid volume : $15 \mathrm{~L}$ ).

Fig. -1 Lipase production of Mucor javanicus IAM 6108 in the presence of limited lipids.

carbon source were studied by use of CzapekDox's medium to increase mycelia, or to decrease the cultivation time. Addition of soybean oil or oleic acid was most effective (Table-1), and the former was chosen in view of cost for the test at the jerfermentor scale.
Table. -4 Effect of carbon sources on the growth of Mycelia of Mucor javanious IAM 6108

\begin{tabular}{l|c}
\hline Carbon sources & $\begin{array}{c}\text { Dry weight of Mycelia } \\
(\mathrm{mg} / 100 \mathrm{~mL} \text { of Broth })\end{array}$ \\
\hline Glucose & 100 \\
Lactose & 9 \\
Maltose & 101 \\
Sucrose & 13 \\
Soluble starch & 203 \\
Glycerol & 10 \\
Stearic acid & 15 \\
Oleic acid & 815 \\
Soybean oil & 722 \\
\hline
\end{tabular}

Basal medium (Czakpek-Dox's medium): $\mathrm{MgSO}_{4} \cdot 7 \mathrm{H}_{2} \mathrm{O} 0.05 \%, \mathrm{NaNO}_{3} 0.2 \%, \mathrm{KCl} 0.05 \%$, $\mathrm{K}_{2} \mathrm{HPO}_{4} 0.1 \%$ and $\mathrm{FeSO}_{4} \cdot 7 \mathrm{H}_{2} \mathrm{O} 0.01 \%$ (initial $\mathrm{pH}: 6.0$ )

Cultivation was carried out for $72 \mathrm{~h}$ at $26^{\circ} \mathrm{C}$ under shaking (110 strokes/min) by use of $500 \mathrm{~mL}-$ Sakaguchi flask (Liquid volume : $100 \mathrm{~mL}$ ).

When cultivation was carried out in the medium containing $1 \%$ of soybean oil, the lipase production was parallel to the growth of Mycelia and the fermentation profile changed from non-growth associated type (Fig. -1$)$ to the growth associated one to reach the maximum value of lipase activity at $30 \mathrm{~h}$. However, lipase activity in broth

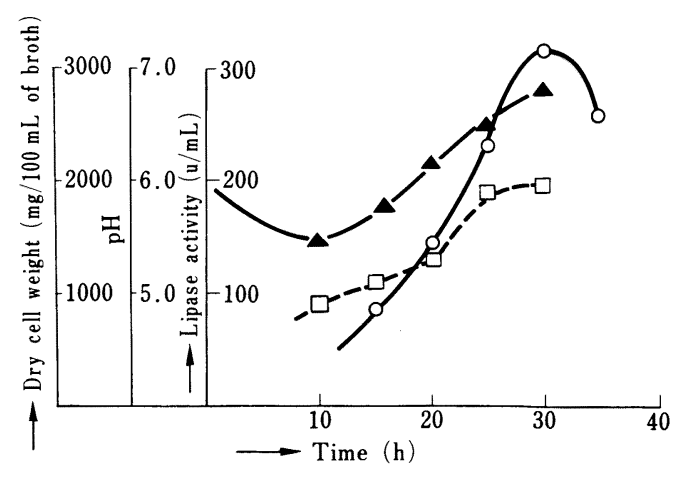

$\mathrm{O}:$ Lipase activity, $\boldsymbol{\Delta}: \mathrm{pH}, \quad \square:$ Dry cell weight

Medium : corn steep liquor $3 \%$, soluble starch $1 \%$, $\mathrm{KH}_{2} \mathrm{PO}_{4} 0.2 \%, \mathrm{MgSO}_{4} \cdot 7 \mathrm{H}_{2} \mathrm{O} 0.05 \%, \mathrm{KCl} 0.05 \%$ soybean-yuto $1 \%$ and soybean oil $1 \%$. Initial $\mathrm{pH}$ was 6. 0 .

Cultivation was carried out at $26{ }^{\circ} \mathrm{C}$, under $300 \mathrm{rpm}$ of agitation and $15 \mathrm{~L} / \mathrm{min}(1 \mathrm{vvm})$ of aeration by use of $30 \mathrm{~L}$-jar fermenter (Liquid volume : $15 \mathrm{~L}$ ).

Fig. -2 Effect of initially added soybean oil on lipase production of Mucor javanicus IAM 6108 . 
decreased rapidly after reaching the maximum value (Fig. -2).

\section{The stabilization of lipase by lipid}

To solve the serious problem on the unstability of lipase in broth, the addition of lipid to the aqueous lipase solution was investigated. Triglycerides and fatty acids with double bonds in fatty acid were effective to stabilize lipase (Fig. -3 a, Fig. $-3 \mathbf{b}$ ).

\section{The Stabilization of Lipase during Culti- vation}

Among effective lipids shown above, soybean oil containing approximately $35 \%$ of triolein was chosen because it was inexpensive and readily available. It was supplemented to become $1 \%$ concentration at $25 \mathrm{~h}$-cultivation prior to the time reaching the maximum value. Lipase activity maintained its maximum value over the range of 10 h (Fig. -4).

\section{Discussion}

When the enzyme is produced in aerobic submerged culture, 30-L jar fermenter is more effective than Sakaguchi flask with respect to the

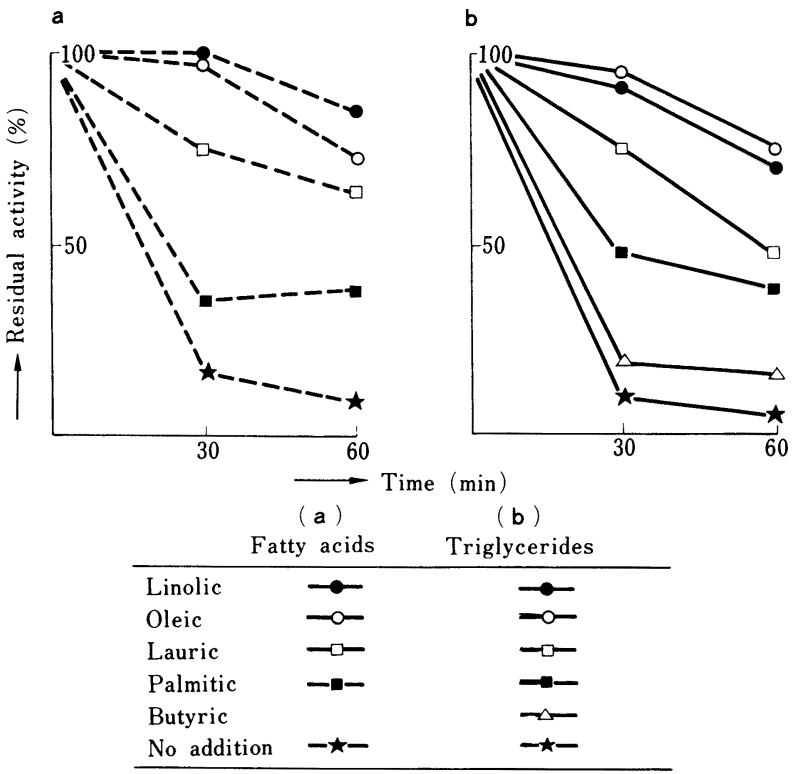

Mucor lipase was dissolved in McIlvain buffer $(\mathrm{pH}$ $8.0)$ to get $0.5 \%$ concentration, kept at $37^{\circ} \mathrm{C}$. The residual activities after $30 \mathrm{~min}$ and $60 \mathrm{~min}$ were assayed. Triglycerides or fatty acids were added to become $5 / 3 \times 10^{-3} \mathrm{M}$ or $5 \times 10^{-3} \mathrm{M}$ respectively.

Fig. -3 The stabilization of Mucor lipase in the aqueous solution by addition of lipids.

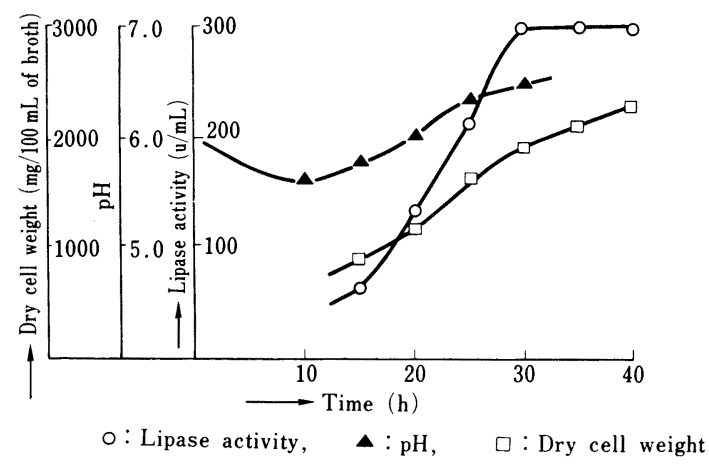

Medium : corn steep liquor $3 \%$, soluble starch $1 \%$, $\mathrm{KH}_{2} \mathrm{PO}, 0.2 \%, \mathrm{MgSO}_{4} \cdot 7 \mathrm{H}_{2} \mathrm{O} 0.05 \%, \mathrm{KCl} 0.05 \%$ soybean-yuto $1 \%$ and soybean oil $1 \%$. Initial $\mathrm{pH}$ was 6.0 .

Cultivation was carried out at $26{ }^{\circ} \mathrm{C}$, under $300 \mathrm{rpm}$ of agitation and $15 \mathrm{~L} / \mathrm{min}(1 \mathrm{vvm})$ of aeration by use of $30 \mathrm{~L}$-jar fermenter (Liquid volume : $15 \mathrm{~L}$ ).

$1 \%$ of soybean oil was supplemented to the broth at $25 \mathrm{~h}$-cultivation prior to the time reaching the maximum lipase activity.

Fig. -4 Effect of supplementation of soybean oil on the stability of lipase excreted in broth during cultivation.

supply of oxygen.

Lipase productivity by Mucor javanicus IAM 6108 increases in proportion to the amount of oxygen supplied ${ }^{9)}$. Therefore, the experiments in this report were carried out under $300 \mathrm{rpm}$ of agitation and $15 \mathrm{~L} /$ $\min (1 \mathrm{vvm})$ of aeration, which is practically the most aerobic condition. $1 \%$ of soybean oil added to initial medium reduced the cultivation time of lipase production.

However, the rapid decrease of lipase activity in broth occured as an unexpected phenomenon which led to the difficulty in deciding the best brothout time. To solve this problem, the improvement of stability in aqueous solution of Mucor lipase was investigated, and the addition of lipids with double bonds in fatty acids were most effective. On the basis of this result, the further addition of soybean oil (adopted from the reason as mentioned in Result-3) during cultivation was successfullv carried out.

The mechanism of the stabilization of lipase by lipids is explained as follows. To obtain the residual activity above 
$50 \%$ under the condition used, it is necessary that the lipids contain double bonds (trilinolein, triolein, linolic acid and oleic acid) or carbon number above approximately 12 in fatty acids (tripalmitin, trilaurin, palmitic acid and lauric acid). Lipids such as tripalmitin, trilaurin, palmitic acid and lauric acid, which are solid at $37^{\circ} \mathrm{C}$, were used after they were melted by heating at the temperature above their melting point prior to adding them to the aqueous lipase solution kept at $37^{\circ} \mathrm{C}$. Then these lipids dispersed into the solution with turbidity and without becoming hard. The difference of effects of those lipids on the stabilization of lipase is presumed not due to the difference of the dispersion rate of lipids, because single chain fatty acid esters which are liquid at room temperature showed the same result as responding free fatty acids or triglycerides. In conclusion, oil drop seems to attach to the surface of enzyme particle, to minimize the contact with water and to stabilize lipase. This phenomenon is similar to that of the improvement on stability by an addition of lecithin or triolein to the aqueous solution of Pseudomonas lipase ${ }^{10)}$.

\section{Acknowledgement}

We are indebted to Prof. K. Arima, Department of Agricultural Chemistry, Faculty of Agriculture, The University of Tokyo, for generous gifts of Mucor javanicus IAM 6108 and soybean-yuto, and for his encouragement.

(Received May 18, 1988)

\section{References}

1) T. Saiki, Y. Takagi, T. Suzuki, T. Narasaki, G. Tamura, and K. Arima, Agric. Biol. Chem., 33, 414 (1969).
2) T. Sugiura, Y. Ota, and Y. Minoda, Agric. Biol. Chem., 39, 1689 (1975).

3) Y. Kosugi and A. Kamibayashi, J. Ferment. Technol., 49, 968 (1971).

4) J. Abe, T. Watanabe, K. Miyajima, T. Yamaguchi, T. Mifuji, and N. Muroya, Japan Koko$k u$, '71-29787.

5) Y. Naka, S. Amano, and K. Yamashita, J. Jpn. Oil. Chem. Soc. (Yukagaku), 35, 459 (1986).

6) H. Chander, V.K. Batish, and OM Parkash, J. Food. Protection, 44, 353 (1981).

7) K. Aisaka and O. Terada, Agric. Biol. Chem., 43, 2125 (1979).

8) Y. Naka, J. Jpn. Oil. Chem. Soc. (Yukagaku), 36, 821 (1987).

9) T. Saiki, T. Narasaki, K. Aramaki, G. Tamura, and K. Arima, Agric. Biol. Chem., 32, 1458 (1968).

10) Y. Naka, Food Chemical, 1986 (7), 63.

ムコール・ジャバニカスによるリパーゼの 生産様相への脂質の添加効果

\section{仲 恭寛・長谷川宣昭・天野 滋 天野製薬株式会社}

（４４81 愛知県西春日井郡西春町大字九之坪西城屋敷 51）

ムコールジャバニカス IAM 6108 のリパーゼをスケー ルアップ生産するにあたり, 培養時間の短縮と培養液の 安定化を試みた。コーンスチープリカー $3 \%$, 可溶性デ ンプン $1 \%$, リン酸二水素カリウム $0.2 \%$, 硫酸マグネ シウム $0.05 \%$, 塩化カリウム $0.05 \%$ 及び大豆油糖 1 $\%$ の基本培地に大豆油 $1 \%$ を添加すると，培養時間は $50 \mathrm{~h}$ から $30 \mathrm{~h}$ に短縮された。一方, 培養中のリパーゼ 活性は最高値に達した後急速に低下した。これを防ぐた め, 最高值に達する時間に先だって, $25 \mathrm{~h}$ で更に大豆油 $1 \%$ を添加すると, 最高値のリパーゼ活性は $10 \mathrm{~h}$ 保持 された。培養液のリパーゼ活性の安定化は, 二重結合を もつ脂肪酸またはトリグリセリドによるものと考えられ た。

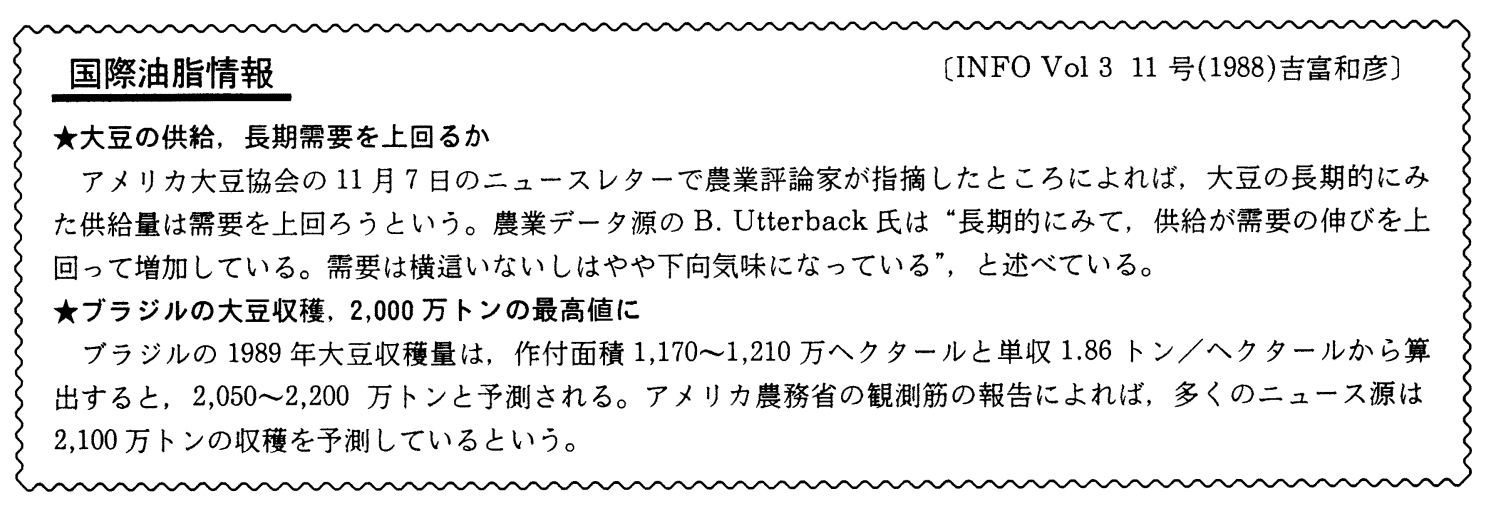

